\title{
Methionine Degradation by Pseudomonas fluorescens UK1 and its Methionine-utilizing Mutant
}

\author{
By S. LAAKSO, EVA SÖDERLING AND V. NURMIKKO \\ Department of Biochemistry, University of Turku, \\ 20500 Turku 50, Finland
}

(Received I I September 1975; revised 23 January 1976)

\begin{abstract}
SUMMARY
Pseudomonas fluorescens UKI, and a mutant derived from it that can use methionine as its sole source of carbon and nitrogen, were used to study methionine degradation. Radioactive 2-oxomethionine, 2-oxobutyric acid and carbon dioxide comprised $95 \%$ of $\left[\mathrm{I}^{-14} \mathrm{C}\right]$ methionine consumed by the mutant. Demethiolating activity was detected in both strains when they were grown with methionine.

The ability to grow on methionine depended on the decarboxylation of 2oxobutyric acid derived from it. This decarboxylating activity was lost if the growth media contained an additional carbon source.
\end{abstract}

No evidence was obtained for the operation of the cystathionine pathway.

\section{INTRODUCTION}

Pseudomonads are known to degrade many commonly-occurring amino acids, but one exception is the sulphur amino acid, methionine (Jakoby, 1964; Stanier, Palleroni \& Doudoroff, I966). Although this plays a central role in sulphur metabolism, relatively little is known about the enzymic reactions involved in its degradative pathway.

A few strains of the genus Pseudomonas which can use methionine as a carbon and nitrogen source have been isolated (Kallio \& Larson, I955; Miwatani, Omukai \& Nakada, I954; Segal \& Starkey, 1969). In these, the methionine sulphur was liberated as volatile methanethiol or its oxidation products in a reaction catalysed by methioninase. The resulting 2-oxobutyric acid was assumed to be decarboxylated to propionic acid (Fig. I).

The inability of some bacteria to grow on methionine may arise because they lack certain enzymes, although the possibility cannot be ruled out that methionine itself is inhibitory, as in Saccharomyces cerevisiae (Yall et al., 1967; Bailey \& Parks, 1972). A convenient way for bacteria to eliminate excess methionine would be to liberate the sulphur as a volatile compound. Thus one might expect some bacteria to possess such an ability whether or not they could grow on methionine as carbon source.

This report compares the properties of a mutant that can use methionine for growth with its parent strain Pseudomonas fuorescens UK I. Using isotopically-labelled methionine, the distribution of the label amongst the supposed catabolites, 2-oxomethionine, 2-oxobutyric acid and carbon dioxide, was determined in order to identify a possible critical point in methionine catabolism.

\section{METHODS}

Chemicals. L-[ $\left.{ }^{-14} \mathrm{C}\right]$ Methionine (specific activity $62 \mathrm{mCi} \mathrm{mmol}^{-1}$ ) and $\mathrm{L}-\left[{ }^{35} \mathrm{~S}\right]$ methionine (specific activity $225 \mathrm{Ci} \mathrm{mmol}^{-1}$ ) were purchased from New England Nuclear (Boston, Massachusetts, U.S.A.); DL-ethionine from Sigma; $S$-methyl-L-cysteine and $S$-ethyl-L- 


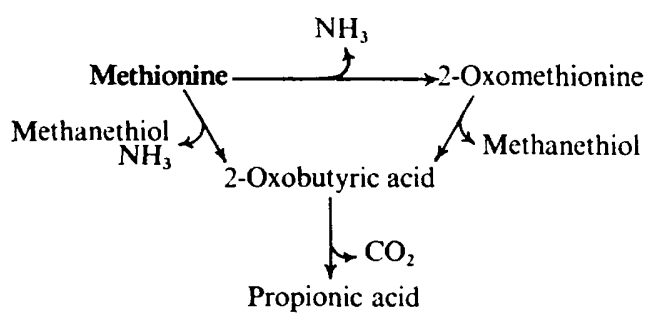

Fig. I. Methionine degradation in Pseudomonads.

cysteine from California Corporation for Biochemical Research (Los Angeles, California, U.S.A.); and L-amino acid oxidase from Calbiochem. 2-Oxomethionine was prepared as described by Meister (1952) and purified by ion-exchange chromatography; DL-homocysteine thiolactone $(\mathrm{HCl})$ was hydrolysed to homocysteine with 2 equiv. $\mathrm{KOH}$; and $\mathrm{L}$-methionine sulphoxide prepared according to the method of Greene (I957).

Bacteria. The principal organisms used were $P$. fluorescens UKI and a mutant derived from it that could use methionine as its sole source of carbon and nitrogen (Mäntsälä, Laakso \& Nurmikko, 1974). The following strains were used as test organisms: P. fluorescens P2 isolated by Goodhue \& Snell (I966), Escherichia coli KI2 (W300I), and S. cerevisiae (ATCC7752).

Culture media. The bacteria were grown in a basal mineral medium containing $\left(\mathrm{g}^{-1}\right)$ : $\mathrm{KH}_{2} \mathrm{PO}_{4}, \mathrm{I} \cdot 35 ; \mathrm{MgSO}_{4} \cdot 7 \mathrm{H}_{2} \mathrm{O}, 0.26 ; \mathrm{FeSO}_{4} \cdot 7 \mathrm{H}_{2} \mathrm{O}, 0.003$, adjusted to $\mathrm{pH} 7 \cdot 2$ with $\mathrm{KOH}$. Unless otherwise stated, the concentrations of the carbon source, methionine and ammonium sulphate (added where necessary as nitrogen source) were all ro mM.

Growth conditions. The organisms were grown in $100 \mathrm{ml}$ of medium in $500 \mathrm{ml}$ flasks with constant shaking at $30^{\circ} \mathrm{C}$. Exponential growth was maintained whilst keeping the turbidity below 50 Klett-readings (filter 62), by diluting if necessary with fresh medium. Before sampling, cultures were grown for several hours, with frequent measurement of turbidity to ensure that a constant growth rate had been established.

Determination of methionine catabolites. Samples containing about $4 \mathrm{mg}$ dry wt bacteria were withdrawn from exponential-phase cultures, centrifuged at $5000 \mathrm{~g}$ for $15 \mathrm{~min}$, washed twice with the basal mineral medium, and suspended in $2 \mathrm{ml}$ of the same medium. Cellfree extracts were made by breaking this suspension at $0{ }^{\circ} \mathrm{C}$ in a sonic oscillator (MSE $60 \mathrm{~W}$ ). Extracts were centrifuged at $5000 \mathrm{~g}$ for $\mathrm{I} 5 \mathrm{~min}$ before use.

Cell suspension $(0.5 \mathrm{ml} ; \mathrm{I} \mathrm{mg}$ dry $\mathrm{wt} / \mathrm{ml})$ or cell-free extract was pipetted into the main chamber of a double side arm Warburg flask. One side arm contained $0.5 \mathrm{ml}$ of io $\mu \mathrm{M}$ $\left[{ }^{1-14} \mathrm{C}\right]$ methionine (specific activity $7.9 \mathrm{mCi} \mathrm{mmol}^{-1}$ ) and the other $0.5 \mathrm{ml}$ of $2 \mathrm{M}-\mathrm{HClO}_{4}$. The centre well contained a filter paper moistened with $0.2 \mathrm{ml}$ of $5 \mathrm{M}-\mathrm{KOH}$ to absorb the radioactive carbon dioxide. After equilibration, the methionine was tipped into the main chamber and incubation at $30^{\circ} \mathrm{C}$ was continued with constant shaking for $30 \mathrm{~min}$. At intervals, $\mathrm{HClO}_{4}$ from the side arm was poured into the main chamber and incubation continued for an additional $15 \mathrm{~min}$ so that all the carbon dioxide liberated from the acidic reaction mixture would be absorbed. The filter papers were air dried and counted for radioactivity in a scintillation spectrometer (Wallac, Decem-NTL ${ }^{314}$ ).

Separation of the 2-oxo acids. The contents of the Warburg vessels were transferred to test tubes and neutralized with $\mathrm{KOH}$. The neutralized supernatant fluids were incubated with $0.5 \mathrm{ml}$ of $2.5 \mathrm{~mm}-2,4$-dinitrophenylhydrazine (in $\mathrm{I} \cdot 2 \mathrm{M}-\mathrm{HCl}$ ) for $30 \mathrm{~min}$ at $30{ }^{\circ} \mathrm{C}$ 
before extracting the 2-oxo acids as their dinitrophenylhydrazones with ethyl acetate (Katsuki et al., 1971). The latter were separated by kieselgel thin-layer chromatography (kieselgel $\mathrm{G}$ in $0 . \mathrm{I} \mathrm{M}-\mathrm{NaHCO}_{3}, \mathrm{I}: 2$, w/v) (Ariga, 1972), extracted from the plates with I \% (v/v) ammonia (in methanol) and counted for radioactivity.

Thin-layer chromatography and autoradiography. Two-dimensional chromatography followed by autoradiography was used to identify components derived from $\left[\mathrm{I}-{ }^{14} \mathrm{C}\right]$ methionine and ${ }^{35}$ S]methionine.

Mutant bacteria growing exponentially on $10 \mathrm{mM}$-methionine were transferred into fresh medium containing $0.6 \mathrm{~mm}$-methionine. This suspension ( $10 \mathrm{ml}$; approx. $0.6 \mathrm{mg}$ dry $\mathrm{wt} / \mathrm{ml})$ was incubated for $30 \mathrm{~min}$ and then supplemented with $\mathrm{I} \cdot 5 \mu \mathrm{Ci}\left[\mathrm{I}-{ }^{14} \mathrm{C}\right]$ methionine (specific activity $62 \mathrm{mCi} \mathrm{mmol}^{-1}$ ) or with $\mathrm{I} \cdot 5 \mu \mathrm{Ci}{ }^{35}$ S]methionine (specific activity $225 \mathrm{Ci}$ mmol-1). After an additional Io min incubation, a $5 \mathrm{ml}$ sample was pipetted into $10 \mathrm{ml}$ of $50 \%$ (v/v) aq. ethanol at $80{ }^{\circ} \mathrm{C}$. The ethanol-insoluble material was centrifuged $(5000 \mathrm{~g}$, $15 \mathrm{~min})$ and the precipitate washed twice with $50 \%(\mathrm{v} / \mathrm{v})$ aq. ethanol and twice with water before hydrolysing with $0.5 \mathrm{ml}$ of $6 \mathrm{M}-\mathrm{HCl}\left(1 \mathrm{IO}{ }^{\circ} \mathrm{C}, 20 \mathrm{~h}\right)$, evaporating to dryness and dissolving in $0.2 \mathrm{ml}$ of water. The supernatant fraction was also evaporated to dryness and dissolved in water $(\mathrm{I} \mathrm{ml})$. Standard compounds were treated with ethanol in a similar manner. Samples were spotted on to t.l.c. plates covered with a mixture of cellulose and kieselgel (cellulose MN 300, silica gel H, 5:I, w/w). Chromatograms were developed first with phenol-water $(78: 28, \mathrm{w} / \mathrm{v})$ and then with n-propanol-water-n-propyl acetate-acetic acid-pyridine (I 20:60:20:4:I, v/v) (Bieleski \& Turner, 1966). The radioactive spots were identified according to their $R_{F}$ values and rechromatographed with appropriate standards.

Determination of demethiolation. The methods described by Challenger (I959) and Segal \& Starkey (1953) were used to detect volatile sulphur products. Demethiolating activity (methioninase) was determined by a procedure based on spectrophotometric determination of a coloured aryl mercaptan produced by a quantitative reaction of 5,5'-dithiobis(2-nitrobenzoic acid) (DTNB) with liberated methanethiol. The standard assay mixture contained $3 \mu \mathrm{mol}$ L-methionine, $0.2 \mu \mathrm{mol}$ DTNB and $0.25 \mathrm{mg}$ dry wt of washed organisms, resuspended in $\mathrm{I} \cdot 0 \mathrm{ml}$ basal mineral medium. The increase in absorbance at $4 \mathrm{I} 2 \mathrm{~nm}$ was followed with a Unicam SP 800 spectrophotometer.

\section{RESULTS}

\section{Occurrence of demethiolating activity in micro-organisms}

A qualitative test to detect volatile sulphur products derived from methionine was made by drawing sterile air through a culture of the mutant $P$. fluorescens, growing exponentially on methionine, into two serial washing bottles, one containing aq. $\mathrm{Hg}(\mathrm{CN})_{2}(3 \%$, w/v) and the other $\mathrm{HgCl}_{2}(3 \%$, w/v). Methanethiol and trace amounts of dimethyl disulphide were the only sulphur compounds identified. For quantitative methanethiol determinations, the DTNB method was used: in this DTNB functions as the primary oxidant and dimethyl disulphide, presumably a product of autoxidation, is determined as methanethiol.

Three strains of $P$. fluorescens (UKI and its mutant, and P2), E. coli $\mathrm{KI} 2$ and $S$. cerevisiae were tested for demethiolating activity. Only the mutant of $P$. fluorescens UKI could utilize methionine as sole source of carbon and nitrogen. Therefore, demethiolating activity was measured in organisms growing exponentially on glucose with Io mM DL-methionine. The rates of demethiolation (per $\mathrm{mg}$ dry wt of organisms) were constant and independent of the time of sampling, indicating steady-state conditions of growth. Methionine was demethiolated by all three cultures of $P$. fluorescens at about the same rate. Escherichia coli and $S$. cerevisiae showed only about I $\%$ of this activity. 

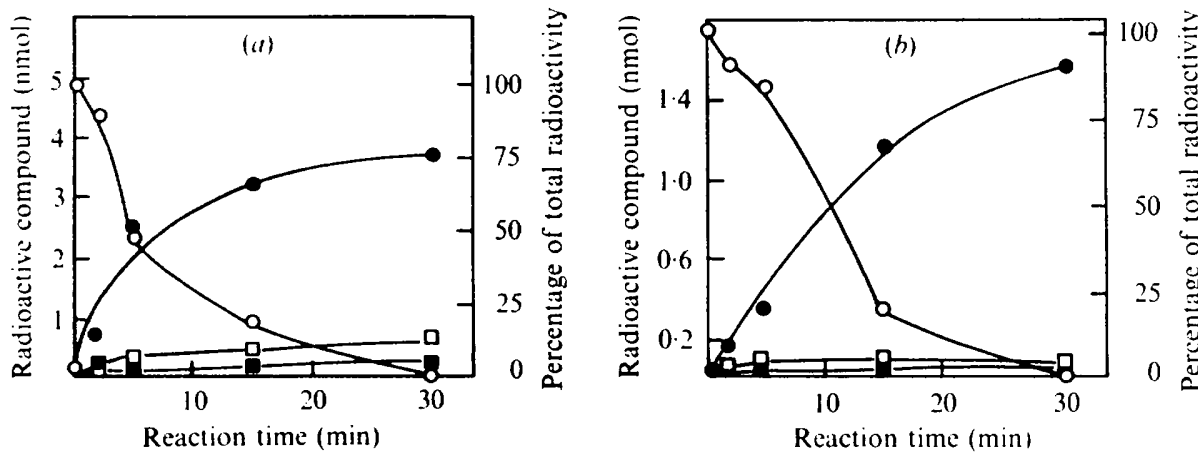

Fig. 2. Distribution of radioactivity derived from $\left[\mathrm{I}^{14} \mathrm{C}\right] \mathrm{methionine}$ amongst 2-oxomethionine, 2-oxobutyric acid and carbon dioxide. Cell-free extracts $(a)$ or washed cell suspensions $(b)$ were prepared from the mutant grown on methionine (IO mM) as carbon and nitrogen source. The experimental conditions were as described in Methods. $O,\left[{ }^{14} \mathrm{C}\right]$ Methionine; $\odot,{ }^{14} \mathrm{CO}_{2} ; \square$, oxo$\left[{ }^{14} \mathrm{C}\right.$ ]methionine; $\mathbf{n}$, oxo[ $\left.{ }^{14} \mathrm{C}\right]$ butyric acid.

\section{Stoichiometry of methionine degradation}

Although $95 \%$ of the catabolic activity was lost during cell disruption, most of the radioactivity of $\left[\mathrm{I}^{14} \mathrm{C}\right]$ methionine was released as ${ }^{14} \mathrm{CO}_{2}$ by both whole cell suspensions $(90 \%)$ and cell-free extracts $(80 \%)$ of the mutant grown on methionine as carbon and nitrogen source.

Radioactive oxo acids which accumulated were separated as their dinitrophenylhydrazine derivatives on kieselgel thin-layer plates with ethyl acetate-methanol $(5: \mathrm{r}, \mathrm{v} / \mathrm{v})$ as solvent. The only labelled oxo acids found were 2-oxomethionine and 2-oxobutyric acid. Of the labelled methionine consumed by whole cells, $95 \%$ was recovered as ${ }^{14} \mathrm{CO}_{2}, 2-\mathrm{oxo}\left[{ }^{\mathrm{I}}{ }^{14} \mathrm{C}\right]-$ methionine and 2-oxo[ $\left.\mathrm{I}^{-14} \mathrm{C}\right]$ butyric acid (Fig. 2a). The corresponding value for cell-free extracts was $88 \%$ (averages of four determinations) (Fig. $2 b$ ).

The possible role of the identified oxo acids as methionine catabolites was tested by determining the distribution of ${ }^{14} \mathrm{C}$ derived from labelled methionine in cell-free extracts supplemented with either 2-oxomethionine or 2-oxobutyric acid (Table I). The latter caused a significant decrease in the rate of labelled $\mathrm{CO}_{2}$ evolution and a nine-fold increase in production of labelled 2-oxobutyric acid. This suggests that decarboxylation of 2-oxobutyric acid rather than 2-oxomethionine is involved in methionine degradation. Neither pyridoxal phosphate nor pyridoxamine had a significant effect on $\mathrm{CO}_{2}$ production from methionine in the presence of 2-oxomethionine, whereas pyridoxamine greatly reduced the radioactivity found in both oxo acids.

$\left[\mathrm{I}-{ }^{14} \mathrm{C}\right]$ Methionine sulphoxide, a poor growth substrate for both the parent and mutant of $P$. fluorescens UK I, was converted into ${ }^{14} \mathrm{CO}_{2}$ at only $5.5 \%$ of the rate of methionine.

\section{Chromatography of methionine catabolites}

Washed suspensions of the mutant and its parent strain were incubated with $\left[{ }^{35}\right.$ S $]$ methionine or $\left[\mathrm{I}^{-14} \mathrm{C}\right]$ methionine and radioactive products were separated by two-dimensional cellulose-kieselgel thin-layer chromatography. Parent and mutant cultures gave identical autoradiograms with both isotopes. Spots I and 2 (Table 2) were identified as methionine and its sulphoxide, methionine sulphoxide being formed spontaneously during ethanol extraction and chromatography. Only two other spots were detectable when $\left[{ }^{14} \mathrm{C}\right]$ methionine was used as substrate. With $\left[{ }^{35} \mathrm{~S}\right]$ methionine the same four spots appeared and, in addition, 
Table $\mathrm{I}$. Effect of supplements on the rate of production of ${ }^{14} \mathrm{CO}_{2}$ and $\left[\mathrm{I}^{14} \mathrm{C}\right]$ oxo acids derived from $\left[\mathrm{I}^{14} \mathrm{C}\right]$ methionine by extracts of the mutant

The reaction mixture contained $0.075 \mu \mathrm{Ci}\left[\mathrm{I}^{14} \mathrm{C}\right]$ methionine (specific activity $7.9 \mathrm{mCi} \mathrm{mmol}^{-1}$ ), and each supplement was added to give a concentration of $\mathrm{I} \cdot 5 \mu \mathrm{mol} \mathrm{ml}{ }^{-1}$.

\begin{tabular}{|c|c|c|c|}
\hline Supplement & $\begin{array}{l}\text { Rate of }{ }^{14} \mathrm{CO}_{2} \\
\text { production } \\
(\% \text { of control) }\end{array}$ & $\begin{array}{l}\text { Rate of oxo- } \\
\text { [I-14C]butyrate } \\
\text { production } \\
\text { (\% of control) }\end{array}$ & $\begin{array}{l}\text { Rate of oxo- } \\
\text { [I-14C]methionine } \\
\text { production } \\
(\% \text { of control) }\end{array}$ \\
\hline None (control) & 100 & 100 & 100 \\
\hline Oxomethionine & $79 \cdot 4$ & 270 & 880 \\
\hline Oxomethionine + pyridoxal phosphate & $65 \cdot 0$ & 550 & 350 \\
\hline Oxomethionine + pyridoxamine & $77 \cdot 0$ & 85 & 80 \\
\hline Oxobutyrate & $28 \cdot 3$ & 930 & 300 \\
\hline
\end{tabular}

Table 2. Radioactive materials produced by washed suspensions of the mutant incubated with $\left[\mathrm{I}^{14} \mathrm{C}\right]$ or $\left[{ }^{35} \mathrm{~S}\right]$ methionine

The compounds were extracted as described in Methods and separated on cellulose-silica gel thin-layer plates $(20 \times 20 \mathrm{~cm})$ by two-dimensional chromatography. Solvent I, phenol-water (78:28, w/v); solvent II, n-propanol-water-n-propyl acetate-acetic acid-pyridine (I20:60:20:4: I, $\mathrm{v} / \mathrm{v})$.

\begin{tabular}{|c|c|c|c|c|c|c|}
\hline \multirow[b]{2}{*}{ Spot no. } & \multicolumn{2}{|c|}{$\left[\mathrm{I}-{ }^{14} \mathrm{C}\right]$ Methionine } & \multicolumn{2}{|c|}{$\left[{ }^{35}\right.$ S]Methionine } & \multicolumn{2}{|c|}{$R_{F}$ values } \\
\hline & $\begin{array}{l}\text { Ethanol } \\
\text { soluble }\end{array}$ & $\begin{array}{l}\text { Ethanol } \\
\text { insoluble }\end{array}$ & $\begin{array}{l}\text { Ethanol } \\
\text { soluble }\end{array}$ & $\begin{array}{c}\text { Ethanol } \\
\text { insoluble }\end{array}$ & Solvent I & Solvent II \\
\hline I & + & + & + & + & 0.70 & $0.6 \mathrm{I}$ \\
\hline 2 & + & + & + & + & 0.70 & 0.37 \\
\hline 3 & + & 0 & + & + & 0.55 & 0.78 \\
\hline 4 & + & 0 & + & 0 & 0.55 & 0.42 \\
\hline 5 & 0 & 0 & + & 0 & 0.76 & 0.80 \\
\hline 6 & 0 & 0 & + & 0 & $0.4 \mathrm{I}$ & 0.65 \\
\hline 7 & 0 & 0 & + & 0 & 0.43 & 0.53 \\
\hline 8 & 0 & 0 & + & 0 & 0.34 & 0.55 \\
\hline
\end{tabular}

there were spots corresponding to four other labelled sulphur compounds (spots 5, 6, 7 and 8). Spots 3 and 4 were present in both ${ }^{35} \mathrm{~S}$ and ${ }^{14} \mathrm{C}$ chromatograms, indicating that these compounds probably had a molecular structure similar to methionine. Spot 4 was also present in the ethanol-insoluble fraction chromatographed after acid hydrolysis, suggesting it was an oxidation product of methionine. The $R_{F}$ values of spots 7 and 8 were similar to those of reduced glutathionine, cysteine or taurine. However, rechromatography with internal standards ruled out these compounds. It is remarkable that the exponential culture did not accumulate detectable intermediates of the cystathionine pathway even when the incubation time was prolonged from to to $30 \mathrm{~min}$ or when the concentrations of radioactive methionine were four times higher $\left(6 \mu \mathrm{Ci}, 225 \mathrm{mCi} \mathrm{mmol}^{-1}\right)$. Some of the radioactive compounds have not been identified. After acidic or alkaline treatment, for instance, cysteine, cystine and cystathionine gave several spots on the chromatograms, but none of them corresponded to those of the radioactive samples.

Since trans-sulphuration from methionine to cysteine could not be detected, either the amounts of cysteine and the components of the cystathionine pathway must be low, or the ultimate source of cysteine sulphur is inorganic sulphate. The effect of inorganic sulphate 
Table 3. Effect of growth substrates on demethiolating activity and on ${ }^{14} \mathrm{CO}_{2}$ production from methionine in cell suspensions of $P$. fluorescens UK I mutant and parent strains

Bacteria were grown in a basal mineral medium supplemented with growth substrates as indicated. Cell suspensions were prepared from exponentially-growing cultures and the activities were determined as described in Methods. Results are expressed as a percentage of the activities found with mutant cells grown on methionine.

\begin{tabular}{|c|c|c|c|c|}
\hline \multirow[b]{2}{*}{$\begin{array}{l}\text { Carbon source for } \\
\text { growth (10 mM) }\end{array}$} & \multicolumn{2}{|c|}{ Mutant strain } & \multicolumn{2}{|c|}{ Wild type } \\
\hline & $\begin{array}{c}\text { Demethiolating } \\
\text { activity }(\%)\end{array}$ & $\begin{array}{c}\text { Rate of }{ }^{14} \mathrm{CO}_{2} \\
\text { production }(\%)\end{array}$ & $\begin{array}{l}\text { Demethiolating } \\
\text { activity }(\%)\end{array}$ & $\begin{array}{c}\text { Rate of }{ }^{14} \mathrm{CO}_{2} \\
\text { production }(\%)\end{array}$ \\
\hline Methionine & 100 & 100 & - & - \\
\hline Methionine + glutamate & $84 \cdot 2$ & 25.0 & $86 \cdot 8$ & $24 \cdot 0$ \\
\hline Glutamate & 10.5 & $28 \cdot 0$ & 10.8 & $26 \cdot 7$ \\
\hline Glucose & $5 \cdot 3$ & $6 \cdot 6$ & $8 \cdot 0$ & $7 \cdot 0$ \\
\hline Oxobutyrate & 10.5 & 43.9 & - & - \\
\hline
\end{tabular}

on the fate of methionine sulphur was studied by cultivating the mutant on methionine as carbon and nitrogen source in a medium deficient in exogenous sulphate. A decrease of $15 \%$ was observed in the ability of the washed organisms to liberate ${ }^{14} \mathrm{CO}_{2}$ from $\left[\mathrm{I}-{ }^{14} \mathrm{C}\right]-$ methionine; demethiolating activity remained unchanged. The products detected by autoradiography and chromatography were also unchanged.

\section{Effect of carbon source on methionine degradation}

Highest demethiolating activities were found in organisms grown in the presence of methionine. When the growth medium contained glutamate in addition to methionine, carbon dioxide production was much lower. On the other hand, the ability to demethiolate methionine was only slightly decreased by the presence of glutamate or glucose in the culture medium (Table 3). When the sole carbon source was glutamate, glucose or 2oxobutyrate, demethiolating activity was diminished to $10 \%$ of that of bacteria grown on methionine.

\section{DISCUSSION}

In $P$. fluorescens UKI and its methionine-utilizing mutant the catabolic reactions of methionine were rather labile. Similar observations were made by Kreis \& Hession (1973) during purification of methioninase from Clostridium sporogenes. In spite of $95 \%$ inactivation, the crude extracts of $P$. fluorescens UK I attacked methionine with almost the same stoichiometry as whole cells. This suggests that the labile point lies at the initial stages of breakdown. 2-Oxobutyric acid may be regarded as a more immediate substrate for decarboxylation than 2-oxomethionine or methionine. However, Ruiz-Herrera \& Starkey (1970) showed that Achromobacter starkeyi, which is able to use methionine for growth, decarboxylates 2-aminobutyric acid more effectively than 2-oxobutyric acid. This may also occur in our Pseudomonas strains.

Artificial enhancement of the 2-oxo acid pools resulted in accumulation of label in these pools. This might indicate that decarboxylation of 2-oxobutyric acid is a rate-limiting step in the degradative pathway so that unlabelled 2-oxobutyric acid at concentrations 150 times higher than methionine saturated the decarboxylative system. The increased label in the 2-oxo acid fractions also suggests that demethiolation is irreversible.

In mammalian cells the conversion of methionine sulphur to cysteine via the cystathionine pathway is important, and this pathway is operative in Neurospora and Saccharomyces 
(Flavin, 1962; Delavier-Klutcko \& Flavin, 1965). If this were the catabolic route in $P$. fluorescens UKI, the ultimate catabolites might be 2-oxobutyric acid and carbon dioxide, and the component determined by the DTNB method might be hydrogen sulphide. However, the operation of the cystathionine pathway as a catabolic route for methionine seems unlikely. Chromatographic analysis of reaction mixtures containing $\left[{ }^{35} \mathrm{~S}\right] \mathrm{methionine}$ or $\left[\mathrm{I}-{ }^{14} \mathrm{C}\right]$ methionine did not reveal any traces of members of the cystathionine pathway. If homocysteine, cystathionine, cysteine or homoserine were catabolites of methionine, it is difficult to believe that they would not have accumulated in detectable amounts, especially when the relatively unstable 2-oxo acids were found.

In most studies of methionine degradation the organisms were cultivated in the presence of methionine. One exception was the study of Kreis \& Hession (1973) on Clostridium sporogenes, from which they extracted methioninase. Further evidence of the constitutive nature of methionine degradation has been presented for Aspergillus sp. by Ruiz-Herrera \& Starkey (1969). In P. fluorescens UKI, demethiolating activity was influenced by the presence of methionine in the medium, both organisms (wild type and mutant) exhibiting their highest demethiolating activities when grown on methionine. These results suggest that the difference between the strains is not in the demethiolation step.

The liberation of carbon dioxide was strongly influenced by the presence of a carbon source in addition to methionine. This, in conjunction with the inability of the wild type to grow at the expense of 2-oxobutyric acid, suggests that 2-oxobutyric acid is one of the components of the methionine catabolic pathway and that the ability to grow on methionine depends on the ability to decarboxylate it.

This work was supported by the Neste Oy:n Säätiö.

\section{REFERENCES}

ARIGA, N. (1972). Thin-layer chromatography of keto acid 2,4-dinitrophenylhydrazones. Analytical Biochemistry 49, 436-44I.

BAIleY, R. B. \& PARKS, L. W. (1972). Response of the intracellular adenosine triphosphate pool of Saccharomyces cerevisiae to growth inhibition induced by excess L-methionine. Journal of Bacteriology III, 542-546.

Bieleski, R. L. \& TURNeR, N. A. (I966). Separation and estimation of amino acids in crude plant extracts by thin-layer chromatography. Analytical Biochemistry 17, 278-293.

Challenger, F. (1959). Aspects of the Organic Chemistry of Sulphur. New York: Academic.

Delavier-Klutcko, C. \& Flavin, M. (1965). Enzymatic synthesis and cleavage of cystathionine in fungi and bacteria. Journal of Biological Chemistry 240, 2537-2549.

Flavin, M. (1962). Microbial transsulfuration: the mechanism of an enzymatic disulfide elimination reaction. Journal of Biological Chemistry 237, 768-777.

Goodhue, C. T. \& SNell, E. E. (1966). The bacterial degradation of pantothenic acid. I. Overall nature of the reaction. Biochemistry, New York 5, 393-398.

Greene, R. C. (1957). Source of the three carbon chain of spermidine. Federation Proceedings I6, I89.

JAKOBY, G. A. (1964). The induction and repression of amino acid oxidation in Pseudomonas fluorescens. Biochemical Journal 92, I-8.

Kallio, R. E. \& LaRson, A. D. (1955). Methionine degradation by a species of Pseudomonas. In A Symposium on Amino Acid Metabolism, pp. 616-631. Edited by W. D. McElroy and H. B. Glass. Baltimore: Johns Hopkins Press.

Katzuki, H., Yoshida, T., TAnegashima, C. \& TANaka, S. (I97I). Improved direct method for determination of keto acids by 2,4-dinitrophenylhydrazine. Analytical Biochemistry 43, 349-356.

KREIS, W. \& HESSION, C. (1973). Isolation and purification of L-methionine- $\alpha$-deamino- $\gamma$-mercaptomethane-lyase (L-methioninase) from Clostridium sporogenes. Cancer Research 33, 1862-1 865.

MÄNTSÄLÄ, P., LAAKso, S. \& NURMikKo, V. (1974). Observations on methionine transport in Pseudomonas fluorescens UKI. Journal of General Microbiology 84, 19-27.

MeISTER, A. J. (1952). Enzymatic preparation of $\alpha$-ketoacids. Journal of Biological Chemistry 197, 309-31 7. 
Miwatani, T., Omukai, Y. \& NAKada, D. (1954). Enzymatic cleavage of methionine and homocysteine by bacteria. Medical Journal of Osaka University 5, 347-352.

Ruiz-Herrera, J. \& Starkey, R. L. (1969). Dissimilation of methionine by fungi. Journal of Bacteriology 99, 544-55I.

Ruiz-Herrera, J. \& Starkey, R. L. (1970). Dissimilation of methionine by Achromobacter starkeyi. Journal of Bacteriology ro4, $1286-1293$.

Segal, W. \& Starkey, R. L. (1953). Quantitative determination of methyl mercaptan, dimethyl disulphide and dimethyl sulphide in a gas mixture. Analytical Chemistry 25, I645-1648.

Segal, W. \& Starkey, R. L. (1969). Microbial decomposition of methionine and identity of the resulting products. Journal of Bacteriology 98, 908-913.

Stanier, R. Y., Palleroni, N. J. \& Doudoroff, M. (1966). The aerobic Pseudomonas: a taxonomic study. Journal of General Microbiology 43, I 59-27I.

Yall, I., Norrel, S. A., JosePh, R. \& KNUDSEN, R. C. (1967). Effect of L-methionine and $S$-adenosylmethionine on growth of an adenine mutant of Saccharomyces cerevisiae. Journal of Bacteriology 93, I 55 I-I 558. 